Jurnal At-Tibyan: Jurnal Ilmu Alqur'an dan Tafsir Volume 5 No. 1, Juni 2020 (h.1-19)

P ISSN 2442-594X | E ISSN 2579-5708

http://journal.iainlangsa.ac.id/index.php/tibyan

\title{
LIVING QUR'AN: TRADISI WIRID AL-MA'TSŪRĀT DI SMAIT ABU BAKAR BOARDING SCHOOL KULON PROGO
}

\author{
The Living Qur'an: Tradition Of Reading Al-Ma'tsürät At Abu Bakar Senior High \\ Islamic Boarding School Kulon Progo
}

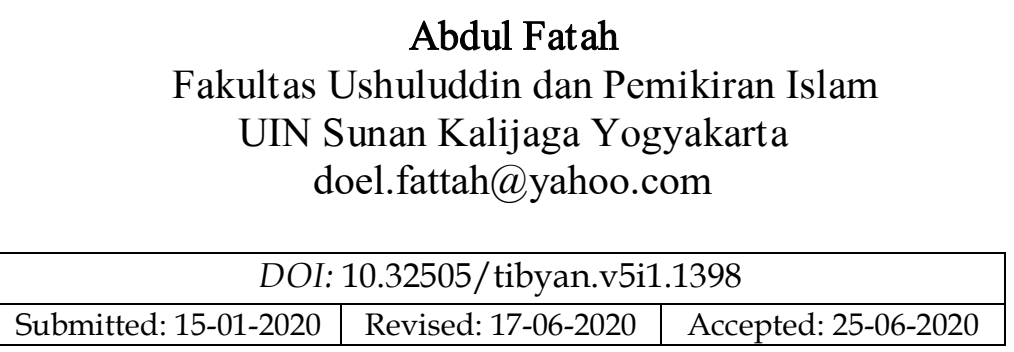

\begin{abstract}
:
This article discusses about the Living Quran study of recitation of wirid alMa'tsūrāt at Abu Bakar Senior High Islamic Boarding School Kulon Progo. It focuses on the practice of wirid al-Ma'tsūrât which is read routine by students at the school. This phenomenon, which has been going on since the school was founded, has positive values for students. They feel the positive impact of the tradition of reciting it in accordance with the function of the Koran as aldzikr (to remembrance of Allah) and al-syifă' (to treat for illness). With the Living Quran method, which is presented by descriptive-analitically method the result is indicate that interaction with the Koran in the form of recitation can provide peace of mind for the reader, whether recited individually or in congregation.
\end{abstract}

Keywords: Living Qur'an, tradition, reading, al-Ma'tsūrāt, Abu Bakar.

\begin{abstract}
Abstrak:
Artikel ini mendiskusikan kajian Living Quran tentang pembacaan wirid alMa’tsūrāt di SMAIT Abu Bakar Boarding School Kulon Progo. Penelitian ini berfokus pada praktik wirid al-Ma'tsūrāt yang menjadi bacaan rutin para siswa di sekolah tersebut. Fenomena yang telah berlangsung sejak sekolah tersebut berdiri, memiliki nilai-nilai positif terhadap para siswa. Mereka merasakan dampak positif dari tradisi pembacaan wirid tersebut sesuai dengan fungsi al-Qur' an sebagai al-dzikr (media dzikir mengingat Allah) dan al-syifã ' (obat bagi penyakit). Dengan metode living quran, yang disajikan dengan deskriptif-analitik hasil penelitian ini menunjukkan bahwa interaksi seseorang dengan al-Qur'an dalam bentuk pembacaan dapat memberikan ketenangan hati bagi pembacanya, baik yang dilakukan secara individual maupun berjamaah.
\end{abstract}

Kata Kunci: Living Qur'an, Tradisi, Wirid, al-Ma'tsūrāt, Abu Bakar.

Hak Cipta @ 2020. Dimiliki oleh Penulis, dipublikasikan oleh Jurnal At-Tibyan: Jurnal Ilmu Alqur'an dan Tafsir.

Artikel dengan akses terbuka. Lisenci: CC-BY

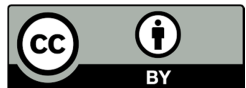




\section{Pendahuluan}

Dalam kedudukan dan fungsinya, al-Qur'an memiliki beragam nama sebagai penyebutan terhadap kitab suci umat Islam tersebut. Salah satunya adalah sebutan alDzikr yang berarti pengingat. Oleh umat muslim, al-Qur'an dapat berfungsi sebagai media berzikir baginya sesuai dengan sebutannya, al-Dzikr. Di dalam al-Qur'an sendiri kata al-Dzikr akan banyak ditemukan dengan segala bentuk dan maknanya (baca QS. al-Anbiya' [21]: 50 dan QS. al-Hijr [15]: 9). Seperti yang terdapat di dalam QS. alRa'du [13]: 28, dengan tegas Allah menyatakan bahwa berdzikir kepada Allah dapat menjadikan hati tenang. Secara tidak langsung, ayat ini memberikan isyarat tentang keutamaan dzikir kepada Allah Swt.

Quraish Shihab dalam tafsirnya mengungkapkan bahwa al-Dzikr pada mulanya berarti mengucapkan dengan lidah. Kendati makna yang berkembang kemudian adalah mengingat. ${ }^{1}$ Hal ini menandakan bahwa lantaran mengingat sesuatu menjadi lidah seseorang akan berulang-ulang untuk menyebutnya dalam ucapan lisannya. Seseorang yang telah berulang-ulang mengucapkan sebuah nama, akan mengantarkan kepada ingatan yang menancap dalam hatinya. Sehingga, dapat dipahami bahwa dzikrullāh atau berdzikir kepada Allah Swt. bermula dari penyebutan nama Allah berulang-ulang yang berimplikasi terhadap ketenangan hati seseorang. Perintah berdzikir kepada Allah Swt. secara eksplisit tersurat dalam QS. al-Baqarah [2]: 152.

Sebagian memahami bahwa al-Dzikr sama halnya dengan dzikir secara umum, baik berupa ayat-ayat al-Qur'an maupun yang lainnya yang diyakini dapat menjadikan hati seseorang menjadi tenang dan tentram. Senada dengan ungkapan ini, Utsman Najati menyatakan bahwa seseorang yang berdzikir, membaca tasbih, istighfar, berdoa dan terbiasa membaca al-Qur'an akan bersih jiwanya sekaligus merasa aman dan ketentraman. ${ }^{2}$ Bahkan, dzikir itu bukan semata-mata mengucapkan dengan lidah saja, melainkan pula mengingat dalam hati akibat ucapan berulang terhadap nama-nama Allah Swt juga disebut dzikir. Orang-orang yang dapat membiasakan dzikir dalam kesehariannya, akan mengantarkan mereka kepada tingkat kesadaran akan kebesaran Allah dan kekuasan-Nya. ${ }^{3}$

Di sisi lain, al-Qur'an juga memiliki fungsi sebagai al-Syifă', yakni menjadi penawar atau obat bagi segala penyakit. Quraish Shihab menyatakan bahwa al-Syifā' di sini biasanya berarti obat yang identik dengan kesembuhan. Menurut sebagian riwayat dikatakan bahwa membaca al-Qur'an dapat menjadi obat bagi penyakit rohani atau kejiwaan. ${ }^{4}$ Karena, sebenarnya penyakit jasmani yang diderita seseorang adakalanya berawal dari penyakit rohani atau kejiwaan. Sehingga, membaca al-Qur'an

\footnotetext{
${ }^{1}$ M. Quraish Shihab, Tafsir Al-Mishbāh, Pesan, Kesan dan Keserasian al-Qur'an, Jilid. VI, I (Jakarta: Lentera Hati, 2002), 271.

${ }^{2}$ Muhammad Utsman Najati, Psikologi Qur'ani; Psikologi dalam Perspektif Al-Qur'an, terj. Amirussodiq (Solo: Aulia Press, 2007), 364.

${ }^{3}$ Shihab, Tafsir Al-Mishbāh, Pesan, Kesan dan Keserasian al-Qur'an, 272.

${ }^{4}$ Shihab, Tafsir Al-Mishbāḥ, Pesan, Kesan dan Keserasian al-Qur'an, 174-175.
} 
diharapkan dapat menyembuhkan penyakit kejiwaan yang berimplikasi terhadap kesehatan jasmani seseorang.

Ada pula sebagian orang yang menempatkan fungsi al-Qur'an sebagai motivator. Sebagian orang tentu hafal ayat dan terjemah QS. al-Insyirah [94]: 5-6. Kedua ayat tersebut menekankan motivasi bagi manusia bahwa di setiap kesulitan pasti ada kemudahan. Pengulangan ayat 6 yang memiliki redaksi sama dengan ayat 5 menunjukkan adanya penekanan sebagaimana para ulama pahami. ${ }^{5}$ Dalam ilmu nahwu, pengulangan semacam itu disebut dengan taukid (penguatan) yang berfungsi mengingatkan dan memantapkan kepada hati manusia, agar dipahami bahwa kesulitan akan selalu ada, yang kemudahan juga akan selalu menyertainya.

Untuk mendapatkan kedua manfaat dari fungsi al-Qur'an tersebut, harus terjadi interaksi dengan al-Qur'an. Salah satu yang dapat dilakukan ialah membacanya. Bentuk pembacaan terhadap ayat-ayat al-Qur'an dikenal dengan tilawah dan qira'ah. Dalam hal ini, tilawah menjadi obyek kajian oleh penulis. Menurut al-Ashfihānī, tilawah berarti aktifitas membaca atau merenungi makna yang berakibat suatu hal baru. ${ }^{6}$ Maka, tilawah al-Qur'an berarti pembacaan ayat al-Qur'an yang berimplikasi pada akibat yang baru. Seperti terdapat dalam al-Qur'an, bahwa orang beriman yang dibacakan al-Qur'an akan semakin bertambah imannya sebagaimana dituturkan QS. alAnfāl [8]: 2.

Kajian Living Quran seperti ini cukup banyak dijumpai dalam beberapa tulisan. Di antaranya adalah artikel berjudul Pemaknaan Ayat Al-Qur'an Dalam Mujahadah: Studi Living Qur'an di PP. Al-Munawwir Krapyak Komplek Al-Kandiyas, tahun 2014. ${ }^{7}$ Dalam artikel ini berfokus kepada kegiatan mujahadah sebagai media untuk mendekatkan diri kepada Allah. Dalam praktiknya, aktifitas ini berupaya menghidupkan al-Qur'an dan dapat berimplikasi langsung terhadap pembacanya bisa berupa ketenangan dan terkabulnya doa pembaca.

Tulisan lainnya adalah artikel berjudul Resepsi terhadap Ayat al-Kursi dalam Literatur Keislaman, tahun 2018. ${ }^{8}$ Artikel ini lebih fokus pada resepsi terhadap ayat alKursi dengan menonjolkan makna fungsional dalam kehidupan. Dalam hal ini, ayat alKursi diklaim memiliki pengaruh transmisi yang bersifat material dan substansial bagi pembacanya. Sedangkan artikel yang terakhir berjudul Pengaruh Zikir al-Ma'tsurat dan Terjemahannya Terhadap Penurunan Kecemasan Siswa Menghadapi Ujian Nasional, tahun 2017. ${ }^{9}$ Artikel ini sama-sama mengkaji pembacaan al-Ma'tsurat seperti kajian penulis. Namun, terdapat perbedaan pada lokasi penelitian dan hasilnya.

\footnotetext{
${ }^{5}$ Shihab, Tafsir Al-Mishbāh, Pesan, Kesan dan Keserasian al-Qur'an, 419.

${ }^{6}$ Rāghib al-Ashfihānī, al-Mufradāt fî Gharīb al-Qur'ān (Beirut: Dār al-Ma'rifah, t.th), 75.

${ }^{7}$ Moh. Muhtador, "Pemaknaan Ayat Al-Qur'an Dalam Mujahadah; Studi Living Qur'an di PP. AlMunawwir Krapyak Komplek Al-Kandiyas”, Jurnal Penelitian 8, no. 1 (2014): 108-109.

${ }^{8}$ Miftahur Rahman, "Resepsi terhadap Ayat al-Kursi dalam Literatur Keislaman", Maghza; Jurnal Ilmu Al-Qur'an dan Tafsir 3, no. 2 (2018): 146

${ }^{9}$ Nur Jannah, "Pengaruh Zikir al-Ma'tsurat dan Terjemahannya Terhadap Penurunan Kecemasan Siswa Menghadapi Ujian Nasional”, Jurnal Studia Insania V, no. 2 (2017): 171-172.
} 
Sependek pembacaan penulis, belum ditemukan kajian living qur'an terhadap tradisi wirid al-Ma'tsūrāt yang terjadi di SMAIT Abu Bakar Boarding School Kulon Progo. Tulisan ini akan terfokus pada fenomena pembacaan wirid al-Ma'tsūrāt di sekolah tersebut. Sehingga, dalam hasilnya nanti akan berusaha mengungkap urgensi wirid al-Ma'tūrāt dan implikasinya bagi siswa yang membacanya rutin setiap hari.

Dalam hal ini, penulis lebih cenderung menggunakan istilah wirid, karena dinilai lebih populer di kalangan masyarakat. Istilah wirid dapat berarti kumpulan ayatayat al-Qur'an dan doa yang biasanya dibaca setelah shalat fardhu, yang juga bisa menunjukkan pekerjaannya. Dalam kata lain, seseorang yang membaca wirid juga tengah melakukan aktifitas wirid yang menjadi fokus dari kajian ini.

Adapun metode penelitian yang akan dilakukan adalah metode Living Quran yang memaknai al-Qur'an sebagai entitas yang bernilai dalam kehidupan. Data-data penelitiannya akan dikumpulkan melalui interview dan kajian pustaka, yang selanjutnya akan dilakukan analisis data dengan metode deskriptif-analitik. Penulis akan mendeskripsikan hasil temuan data secara sistematis dan faktual berdasarkan data yang dikumpulkan. Sehingga, hasil penelitian ini diharapkan cukup memberikan gambaran tentang tradisi wirid yang dilakukan para siswa di SMAIT Abu Bakar Boarding School Kulon Progo.

\section{Living Qur'an Sebagai Resepsi Terhadap Al-Qur'an}

Al-Qur'an sebagai kitab petunjuk bagi umat Islam memiliki posisi sentral bagi pembacanya. Untuk mendapatkan petunjuk yang terkandung di dalam al-Qur'an, seseorang harus membaca dan merenungi hasil bacaannya. Dengan membacanya, seseorang dapat menanggapi obyek bacaannya dalam bentuk reaksi tertentu sebagai bentuk resepsi terhadap al-Qur'an. Hal ini sebagaimana diungkapkan oleh Asia Padmopuspito, bahwa sebuah karya sastra dapat diberikan makna oleh pembacanya dalam bentuk reaksi atau tanggapan baik secara aktif maupun pasif. ${ }^{10}$ Sehingga, seorang pembaca al-Qur'an dapat merealisasikannya dalam kehidupan atau sekadar memahami maknanya tersebut.

Sebagaimana dikemukakan oleh Ahmad Rafiq bahwa resepsi terhadap alQur'an mengandung arti bagaimana reaksi seseorang terhadap al-Qur'an yang meliputi cara menerima, memanfaatkan, merespon, hingga menggunakannya. Bisa dikatakan resepsi semacam ini telah dilakukan oleh sahabat Nabi dan setelahnya dalam rangka memahami dan mempraktikkan kandungan al-Qur'an. ${ }^{11}$ Sehingga, resepsi terhadap alQur'an ini berhasil menciptakan beragam fenomena sosial dalam mentransformasikan nilai-nilai di dalamnya.

Transformasi nilai-nilai al-Qur'an dapat timbul ketika terdapat interaksi pembacaan al-Qur'an oleh masyarakat. Seorang pembaca al-Qur'an dinilai akan

\footnotetext{
${ }^{10}$ Asia Padmopuspito, "Teori Resepsi dan Penerapannya", Jurnal Diksi 1, no. 02, (1993): 73.

${ }^{11}$ Ahmad Rafiq, "Sejarah Al-Qur'an: Dari Pewahyuan ke Resepsi (Sebuah Pencarian Awal Metodologis)", dalam Sahiron Syamsuddin, Islam, Tradisi dan Peradaban (Yogyakarta: Bina Mulia Press, 2012), 73-74.
} 
mampu menghidupkan nilai-nilainya di dalam kehidupan. Inilah yang dimaksud dengan Living Qur'an. Sahiron Syamsuddin mendefinisikan bahwa Living Qur'an ialah teks al-Qur'an yang hidup dalam masyarakat. Artinya, teks tersebut bergumul dalam ranah realitas yang direspons oleh masyarakat secara langsung. Resepsi sosial terhadap alQur'an dapat ditemui dalam kehidupan sehari-hari, seperti tradisi membaca ayat-ayat atau surah tertentu dari al-Qur'an pada momen dan seremoni keagamaan tertentu. ${ }^{12}$

Fenomena ini menandakan bahwa resepsi terhadap al-Qur'an sebagai sebuah teks berbahasa Arab lebih kepada ranah praktis dibandingkan pemahaman terhadap makna dan kemudian baru dipraktikkan. Penerimaan semacam ini sebenarnya didasarkan kepada pola pikir dan keyakinan seorang muslim terhadap kesucian dan kemuliaan al-Qur'an. Pada proses ini, terlepas apakah seorang muslim mau membacanya dan memahami kandungannya, atau tidak membaca sama sekali. Keduanya kembali pada satu aturan bahwa pola pikir semacam ini yang membuka aneka kreatifitas yang terjadi pada generasi selanjutnya sesuai dengan konteks pelaku praktiknya. ${ }^{13}$

Sementara itu, meminjam pendapat Muhammad Yusuf bahwa Living Qur'an merupakan upaya untuk membuat hidup dan menghidup-hidupkan al-Qur'an yang dilakukan oleh masyarakat, sebagai respons sosial terhadapnya. ${ }^{14}$ Mengutip Hamam Faizin, bahwa metode Living Quran tidak bertujuan mencari kebenaran positivistik, yang selalu melihat konteks. Metode ini berupaya melakukan pembacaan obyektif terhadap fenomena keagamaan yang berkaitan langsung dengan al-Qur'an. ${ }^{15}$ Sehingga, dapat dipahami bahwa studi Living Qur'an bukan pada ranah tekstualnya, melainkan lebih fokus terhadap fenomena sosial masyarakat yang timbul dari kehadiran al-Qur'an di dalamnya. Fenomena sosial yang terjadi pada suatu masyarakat inilah yang dapat berimplikasi membentuk tradisi tertentu di dalam kehidupan mereka.

Sebagaimana dipahami bahwa tradisi itu muncul karena ada respons dari masyarakat terhadap suatu obyek yang telah menjadi kebiasaan. Sebagaimana tradisi membaca al-Qur'an yang menjadi bagian dari fenomena sosial, tentu bermula dari upaya masyarakat untuk menghidupkannya di tengah kehidupan mereka. Kedudukan al-Qur'an bagi setiap muslim dalam praktiknya, bukan lagi hanya sebagai way of life yang membimbingnya, melainkan telah menjadi kehidupan bagi seorang muslim itu sendiri. ${ }^{16}$

Dalam hal ini, al-Qur'an selain sebagai kitab suci juga sebagai mediator bagi manusia berdialog dengan Tuhannya untuk menggapai hikmah dan nilai ajaran yang menciptakan kedamaian dalam kehidupan. Tradisi membaca al-Qur'an, baik pada ayatayat tertentu maupun secara keseluruhan merupakan wujud dari upaya mencapai

\footnotetext{
${ }^{12}$ Sahiron Syamsuddin, "Ranah-ranah dalam Penelitian Al-Qur'an dan Hadis", dalam Kata Pengantar Metodologi Living Qur'an dan Hadis (Yogyakarta: Teras, 2007), xviii-xiv.

${ }^{13}$ Rafiq, "Sejarah Al-Qur'an: Dari Pewahyuan ke Resepsi, 74-75.

${ }^{14}$ Yusuf, "Pendekatan Sosiologi dalam Penelitian Living Qur'an", dalam Metodologi Living Qur'an dan Hadis, 36.

${ }^{15}$ Hamam Faizin, “Mencium dan Nyunggi Al-Qur'an”, Jurnal Suh uf 4, no. 1 (2011): 39

${ }^{16}$ Rafiq, “Sejarah Al-Qur'an: Dari Pewahyuan ke Resepsi, 81
} 
kebahagiaan hidup bagi umat muslim. Semua itu terlepas dari apakah praktik tersebut berangkat dari pembacaan dan pemahaman atau tidak tidak sama sekali. Sehingga, tradisi tersebut boleh dikatakan terbentuk secara organik tanpa harus menanamkan doktrin pemahaman al-Qur'an terlebih dahulu.

\section{Tradisi Membaca Al-Qur'an Sebagai Wirid}

Al-Qur'an sebagai sumber utama bagi ajaran Islam berkedudukan sangat penting yang bukan sekadar untuk menentukan hukum-hukum Islam. Di sisi lain, juga memiliki keistimewaan mengundang daya tarik bagi pembacanya. Bagi muslim, membaca al-Qur'an dinilai sebagai ibadah. ${ }^{17}$ Seorang muslim yang tidak pandai membaca al-Qur'an akan dinilai kurang baik di mata masyarakatnya. Oleh karena itu, dengan belajar membaca, memperbaiki bacaan, menerjemahkan sampai menghafalkannya menjadi satu keunggulan tersendiri bagi umat muslim terhadap kitab suci yang mereka yakini.

Sepanjang sejarah umat Islam, al-Qur'an telah menjadi bagian tidak terpisahkan bagi setiap muslim. Sejak kali pertama diwahyukan kepada rasulullah hingga kini, alQur'an selalu mendapat tempat khusus bagi para pembaca dan penghafalnya. Dalam hal ini, al-Qur'an tiada hentinya dibaca dan dihafal semua kalangan tanpa melihat latar belakang dan usia. ${ }^{18}$ Hal ini menandakan betapa besarnya sambutan besar umat muslim menghidupkan al-Qur'an di tengah-tengah kelangsungan hidup mereka. Sebagian mereka pula ada yang menjadikan al-Qur'an sebagai rutinitas harian yang jarang ditinggalkan.

Abdullah Saeed menyatakan bahwa membaca al-Qur'an telah menjadi bagian sentral dari praktik keagamaan seorang muslim. Banyak di antaranya, membaca alQur'an hanya sebagai pembuka dalam doa sehari-hari dan ada juga demi kepentingan kompetisi keindahan baca al-Qur'an. Namun, yang tak kalah pentingnya ialah membacanya dalam segala kegiatan formal maupun informal. Semua hal itu, lazim dilakukan oleh umat muslim di seluruh dunia. Tidak heran apabila hari ini setiap rumah seorang muslim memiliki satu al-Qur'an versi cetak sebagai salah satu koleksinya. ${ }^{19}$ Sehingga, setiap muslim hampir tidak ketinggalan untuk dapat melihat atau merasakan hegemoni al-Qur'an sebagai part of daily life mereka.

Dilihat dari sisi kandungannya, al-Qur'an bukan hanya berisi tentang aturan yang bersifat teologis saja. Akan tetapi, ketika mau menelusuri lebih jauh dan mendalam akan ditemukan universalitas al-Qur'an bagi perilaku kehidupan umat manusia. Dapat dikatakan bila al-Qur'an memuat tuntunan teoritis dan praktis. Untuk mendapatkan itu semua, umat muslim harus membaca dan merenungi kandungan makna ayat-ayatnya. Dengan demikian, tradisi pembacaan al-Qur'an harus digalakkan bukan sekadar hanya membaca ayat-ayat tersurat, melainkan juga dijadikan pandangan hidup.

\footnotetext{
${ }^{17}$ Subhi Shalih, Mabāhits fì Uhūm al-Qur'ān (Beirut: Dar al-'Ilmi li al-Malayin, 1977), 21.

${ }^{18}$ Abdullah Saeed, The Qur'an An Introduction (New York: Routledge, 2008), 84.

${ }^{19}$ Saeed, The Qur'an An Introduction, 84.
} 
Secara substansial, al-Qur'an mengajarkan norma dan praktik yang bersifat universal maupun spesifik menurut budaya dan masa tertentu. Ini merupakan akibat dari praktik masyarakat muslim yang menempatkan al-Qur'an sebagai benda suci dan firman Tuhan yang wajib dihormati. Di sinilah letak pentingnya interaksi dengan alQur'an bukan saja dianggap sebagai teks biasa, namun butuh ritus tertentu untuk sekadar memegang dan membacanya. Bagi muslim, sebelum membacanya harus dalam keadaan suci terlebih dulu. Karena, membaca al-Qur'an menjadi satu bagian dari ibadah baik dalam shalat maupun kondisi lainnya. ${ }^{20}$

Sebagaimana tersurat dalam QS. al-Qamar [54]: 17, Allah sendiri telah menjamin kemudahan al-Qur'an untuk dijadikan sebagai pengingat bagi pembacanya. Wahbah Zuhaili menuturkan bahwa kemudahan al-Qur'an yang dimaksud dalam ayat ini bukan sekadar mudah untuk dibaca, tapi juga mudah untuk dihafal dan diingat-ingat pelajaran di dalamnya. Ayat ini terulang sebanyak empat kali dalam satu surah. Pengulangan tersebut mengindikasikan adanya penegasan peringatan terhadap pembaca agar dapat mengambil pelajaran berharga dari kisah-kisah umat terdahulu yang diabadikan Allah dalam surah ini. ${ }^{21}$ Pengulangan tersebut setidaknya menandakan ketegasan Allah dalam memberikan peringatan bagi kaum muslimin. Sehingga, pembacaan berulang-ulang terhadap al-Qur'an dalam menjadikannya menancap kuat dalam hati dan senantiasa terbayang dalam ingatan.

Di dalam al-Qur'an, tidak dapat ditemukan ayat yang secara tersurat menunjukkan aktifitas pembacaan al-Qur'an dengan kata wirid. Istilah ini memang tidak populer di kalangan orang Arab, yang mungkin lebih cenderung fasih menggunakan kata tilawah atau pun qira'ah yang menunjukkan arti membaca alQur'an. Namun, di kalangan masyarakat muslim yang secara khusus di Indonesia istilah wirid lebih populer sebagai bagian yang tidak terpisahkan dari rutinitas mereka sehari-hari. Wirid telah menjadi bagian penting bagi keberagamaan masyarakat muslim Indonesia.

Dalam Kamus Besar Bahasa Indonesia, kata wirid berarti kutipan-kutipan (ayat) al-Qur'an yang ditetapkan untuk dibaca atau zikir yang diucapkan sesudah shalat. Ketika kata wirid berkedudukan sebagai kata kerja, dapat diberi imbuhan medan -an, menjadi mewiridkan atau wiridan dapat berarti membaca wirid, mengamalkan wirid, atau menjadikan wirid. ${ }^{22}$ Dari pengertian tersebut, penulis lebih cenderung memahami bahwa wirid lebih identik dengan fungsi al-Qur'an sebagai al-dzikr, yang dalam hal ini al-Qur'an menjadi pengingat bagi kehidupan seorang muslim. Sehingga, bisa dikatakan bahwa istilah wirid diwakili dengan kata al-dzikryang digunakan dalam bahasa ungkapan al-Qur'an.

Dalam persoalan dzikir, dengan mengutip al-Biqā̄'̄̄ Quraish Shihab menyatakan bahwa dzikir berarti mengingat Allah di hati dan menyebutnya dengan lidah seraya

\footnotetext{
${ }^{20}$ Saeed, The Qur'an An Introduction, 85.

${ }^{21}$ Wahbah al-Zuhaily, al-Tafsìr al-Mun̄̄r fì al- 'Aqūdah wa al-Syañ̄'ah wa al-Manhaj, Cet. Ke-10, Jilid XIV (Beirut: Dār al-Fikr, 2009), 170.

${ }^{22}$ Lihat di https://kbbi.web.id/wirid yang diakses pada 06 Oktober 2019 pukul 14.25 WIB.
} 
menghadirkan sifat-sifat dan keagungan Allah Swt. Adapun bentuk dzikir, itu meliputi dua hal, yakni al-dzikr bi al-lisān yang meliputi membaca al-Qur'an, menuntut ilmu dan melakukan studi atau penelitian dan al-dzikr bi al-qalb yang berarti mengingat Allah dengan hati, dalam semua perintah dan larangan-Nya. ${ }^{23}$ Demikian penjelasannya dalam menafsirkan kata al-dzākin̄n Allāh dalam QS. al-Ahzab [33]: 35. Maka, dzikir dapat dipahami sebagai aktifitas mengingat Allah dengan menyebut nama-Nya secara lisan dalam rangka merenungkan keagungan sifat-sifat dan kesempurnaan-Nya.

Secara tegas perintah Allah untuk memperbanyak dzikir dan bertasbih di waktu pagi dan petang diungkapkan dalam QS. al-Ahzab [33]: 41-42. Allah berfirman:

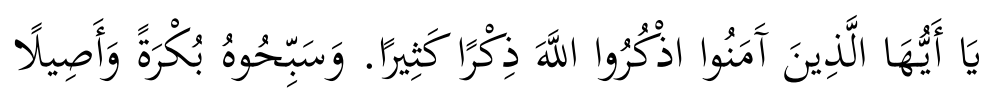

Artinya: "Hai orang-orang yang beriman, berzdikirlah (dengan menyebut nama) Allah, zikir yang sebanyak-banyaknya. Dan bertasbihlah kepada-Nya diwaktu pagi dan petang." (QS. al-Ahzab [33]: 41-42). ${ }^{24}$

Banyak ayat dan hadis yang memerintahkan manusia untuk memperbanyak dzikir. Kedua ayat di atas menjadi satu ayat yang secara tegas berisi perintah untuk memperbanyak dzikir dan bertasbih di waktu pagi dan petang. Namun, sebagian ulama menafsirkan ayat ini sebagai perintah untuk memperbanyak shalat. Pada kedua ayat tersebut, Quraish Shihab mengungkapkan bahwa dzikir itu tidak terbatas pada satu akfititas tertentu. Akan tetapi, dapat diartikan lebih luas lagi sebagai aktifitas yang dapat mengingatkan seseorang akan kehadiran dan keagungan Allah Swt. ${ }^{25}$ Maka, hemat penulis dzikir dapat diartikan sebagai aktifitas apa saja yang dapat mengingatkan seseorang akan kehadiran Allah, baik dalam menjalankan perintah dan meninggalkan larangan-Nya.

Berdasarkan pemaparan di atas, dapat dipahami bahwa dzikir bukan sekadar mengingat saja. Dzikir berarti mengingat Allah baik dengan lisan maupun dengan hati. Karena, dalam hal ini dzikir lebih mengarah kepada upaya untuk menghubungkan jiwa manusia dengan Allah Swt. dan merasakan kehadiran dan keagungan sifat-Nya. Salah satunya, yang sangat mudah untuk diamalkan ialah membaca al-Qur'an.

Membaca al-Qur'an tidak saja patut dijadikan sebagai kewajiban setiap individu. Namun, juga perlu dibiasakan menjadi sebuah tradisi yang dapat menunt un kehidupan sehari-hari. Membaca al-Qur'an bisa juga diibaratkan sebagai media bermunajat dan berdoa kepada Allah Swt. ${ }^{26}$ Karena itulah, bacaan al-Qur'an berupa ayat-ayat pilihan yang dibuat dalam susunan tertentu dapat dijadikan sebagai media untuk berdzikir kepada Allah Swt. Dalam hal ini, kitab al-Ma'tsūrāt karya Hasan alBana dapat dikatakan sebagai kitab wirid yang memuat kutipan-kutipan ayat al-Qur'an dan doa-doa yang berlandaskan kepada hadis-hadis shahih.

\footnotetext{
${ }^{23}$ Shihab, Tafsir Al-Mishbāh, Pesan, Kesan dan Keserasian al-Qur'an, 474-477.

${ }^{24}$ Q.S. al-Ahzab/33: 41-42

${ }^{25}$ M. Quraish Shihab, Tafsir Al-Mishbāh, Pesan, Kesan dan Keserasian al-Qur'an, 4494-495.

${ }^{26}$ Saeed, The Qur'an An Introduction, 86.
} 
Dengan demikian, aktifitas membaca al-Qur'an bukan sekadar melihat dan melafazkan susunan ayat-ayatnya berdasarkan hukum dan ketentuannya. Membaca alQur'an justru harus diupayakan menjadi suatu tradisi yang dapat diamalkan oleh seluruh lapisan masyarakat. Tujuannya adalah dalam rangka mencari keutamaan dan memperoleh kemanfaatan fungsinya sebagai al-syifă' (obat). Inilah relevansi fungsi alQur'an sebagai al-Dzikr yang sudah seharusnya menjadi media wiridan dan amalan harian.

\section{Profil Kitab Al-Ma'tsūrāt dan Penulisnya}

Dalam kedudukannya, al-Qur'an memiliki banyak fungsi bagi kehidupan umat manusia. Secara eksplisit, perintah untuk membaca al-Qur'an tersurat dalam QS. al'Alaq [96]: 1-3. Al-Qur' an juga menjadi obyek kajian yang menarik dan tidak pernah ada habisnya. Ada juga sebagian umat muslim menjadikannya sebagai media berdzikir dan juga media pengobatan yang dapat menyembuhkan penyakit jasmani maupun rohani. Terlepas dari semua itu, semangat untuk membaca dan mengkaji al-Qur'an tidak boleh berhenti pada satu persoalan dan akan terus berkembang mengikuti zamannya.

Dari sisi bahasa, al-Ma'tsūrāt merupakan bentuk plural dari kata al-Ma'tsūr yang merupakan bentuk maf'ul dari kata atsara. Dalam kamus al-Munawwir, kata atsara bermakna mengutip atau menyebutkan. ${ }^{27}$ Jadi, kata al-ma'tsūr berarti yang dikutip atau yang disebutkan. Di dalam kajian ilmu al-Qur'an juga sering disebutkan kata al-ma'tsūr yang dikaitkan dengan tafsir. Menurut al-Zarqān̄̄, tafsir bi al-ma'tsūr adalah tafsir yang didasarkan kepada ayat al-Qur'an, sunnah dan atsār (perkataan sahabat). ${ }^{28}$ Berdasarkan pengertian tersebut dapat dipahami bahwa al-Ma'tsūrāt merupakan kumpulan bacaan-bacaan yang meliputi ayat-ayat al-Qur'an dan doa-doa yang dikutip dari hadis-hadis Nabi Saw.

Kitab al-Ma'tsūrāt disusun oleh Syekh Hasan al-Bana (1324-1368 H). Nama aslinya Hasan bin Ahmad bin Abdur Rahman al-Bana. Ia lahir di Mahmudiyah (dekat dengan Iskandariyah), Mesir pada tahun 1906 M (1324 H). Ia dibesarkan dalam keluarga yang amat kuat berpegang pada Islam. Abdurrahman al-Bana adalah kakeknya yang merupakan pembesar di wilayah Syam Syiria. Ayah Hasan al-Bana merupakan seorang ulama yang sangat hebat dalam bidang keilmuan. Selain menjadi ulama, beliau berprofesi sebagai tukang reparasi jam dan penjilidan buku. Sehingga, ayahnya dikenal dengan julukan al-Syaikh al-Sa'ati. Pekerjaan sebagai tukang jam dilakoni pada malam hari. Sedangkan, pada siang harinya menjadi imam di salah satu masjid di desanya. Hal ini menjadi satu pengajaran tentang prinsip-prinsip Islam dan berdakwah. ${ }^{29}$

\footnotetext{
${ }^{27}$ Ahmad Warson Munawwir, Kamus Al-Munawwir, Cet. XIV (Surabaya: Penerbit Pustaka Progressif, 1997), 6.

${ }^{28}$ Muhammad Abdul Azhim al-Zarqānī, Manāhil al- 'Irfān fì Uhūm al-Qur'ān, Jilid II (Mesir: İsā alBāb al-Halabī, t.th), 12.

${ }^{29}$ Raudhatul Jannah, "Pemikiran Pendidikan Islam Hasan Al-Bana", Jurnal Analytica Islamica 6, no.1 (2017): 69.
} 
Hasan al-Bana memulai pendidikannya di Madrasah al-Rasyad al-Diniyah untuk menghafal al-Qur' an dan hadis-hadis nabi. Di samping itu, Ia juga belajar terkait dasardasar keilmuan bahasa Arab dibimbing oleh Syekh Zahran, yang merupakan salah satu pengikut tarekat Shufi al-Hashafiyyah. Selanjutnya, al-Bana melanjutkan pendidikannya di Madrasah I'dadiyah. Pada saat yang sama, Ia sedang berusaha untuk menyelesaikan hafalan al-Qur'annya setelah berjanji kepada ayahnya. Di tempat inilah, Ia mulanya berkenalan dengan organisasi dan perkumpulan. Ia kemudian menapaki gerakan dakwah melalui organisasi Jum'iyyat al-Akhlaq al-Adabiyah dan menjabat sebagai ketuanya.

Setelah melanjutkan pendidikan ke Madrasah al-Mu'allimin, di sana Ia mulai berkenalan dengan dunia tarekat Shufi al-Hashafiyyah. Ia sangat tercengang ketika mendapati Syekh Zahran, guru yang pernah mengajarnya dulu sama-sama bergabung di dalam tarekat tersebut. Setiap pagi dan petang hari al-Bana aktif dan rutin membiasakan dzikir al-Ruzuqiyyah. Di samping itu, Ia bersama teman-temannya juga aktif dalam kegiatan maulid Nabi Saw. dan juga ziarah kubur. Sehingga, pada akhirnya Ia berbaiat kepada syekh Basyuni Abdul Jabir Rizq. Setelah resmi menjadi pengikut tarekat tersebut, Ia pun mendapat Ijazah wirid-wirid tarekat dari gurunya. ${ }^{30}$

Pada pendidikan selanjutnya, Ia masuk ke Universitas Darul Ulum Mesir pada tahun 1923. Ia lulus dari Darul Ulum pada tahun 1927, yang kemudian diangkat menjadi guru setelah gagal rencananya untuk mendapatkan beasiswa belajar ke luar negeri dikarenakan Mesir sedang mengalami kekurangan guru. Karena itu, waktu siangnya Ia gunakan untuk mengajar anak-anak dan pada malam harinya mengajar para orang tua. ${ }^{31}$ Aktifitas ini menunjukkan dedikasinya terhadap dunia pendidikan di Mesir saat itu. Hal ini sangat mempengaruhi terhadap pembentukan kepribadiannya di masa depan.

Dari riwayat hidup di atas, dapat dipahami bahwa al-Bana merupakan salah seorang ulama yang tumbuh dan berkembang dari lingkungan Islam yang kuat semenjak kecilnya. Perjalanan karier keilmuannya mengantarkan pada sebuah kedudukan sebagai orang penting yang di berbagai organisasi. Hingga akhirnya Ia mendirikan organisasi Ikhwan al-Muslimin. Dalam kedudukannya sebagai pemimpin, Ia menyusun kitab al-Ma'tsūrāt yang berisi bacaan-bacaan wirid dan doa yang ma'tsur dari al-Qur'an dan hadis. Penyusunan kitab tersebut tidak terjadi secara tiba-tiba. Akan tetapi, riwayat pendidikan al-Bana memiliki hubungan erat dengan kehidupan thariqah yang selama ini diikutinya.

Kitab al-Ma'tsūrāt memiliki empat bagian sebagai berikut:

a. al-Wazhīfah. Pada bagian ini berisi ayat-ayat al-Qur'an yang disusun tartib surah dalam al-Qur'an. Kemudian, bagian ini juga dilengkapi doa-doa yang ma’tsur dari hadis-hadis rasulullah Saw. Secara keseluruhan bagian ini

\footnotetext{
${ }^{30}$ Otoman, "Pemikiran Politik Hasan Al-Bana dan Pembentukan Radikalisme Islam", Jurnal Tamaddun 15, no. 1 (2015): 68-69.

${ }^{31}$ Jannah, "Pemikiran Pendidikan Islam Hasan Al-Bana", 69. 
disebut al-Wazhifah al-Kubrā. Namun, apabila tidak memiliki waktu cukup banyak atau ingin membaca sendirian bagian ini boleh diringkas, yang kemudian disebut al-Wazhz̄ fah al-Shughrā. Di antara ayat al-Qur'an yang terdapat dalam al-Wazhīfah al-Sughrā adalah QS. al-Fatihah [1]: 1-7; QS. alBaqarah [2]: 1-5, 255-257, 284-286; QS. al-Ikhlas [112]: 1-4; QS. al-Falaq [113]: 1-5; QS. al-Nas [114]: 1-6.

b. al-Wird al-Qữ̄n̄ì. Pada bagian ini tentang keutamaan al-Qur'an dan anjuran untuk menjadikan al-Qur'an sebagai wirid sehari-hari. Motivasi untuk membaca al-Qur'an pada bagian ini dilengkapi hadis-hadis rasulullah Saw. yang berisi tentang keutamaan dan anjurannya.

c. Ad'iyah al-Yaum wa al-Lailah (doa sehari semalam). Pada bagian ini terdapat doa-doa yang menuntun kegiatan sehari-hari mulai bangun tidur sampai hendak tidur kembali.

d. al-Ad'iyah al-Ma'tsūrah lainnya. Pada bagian ini terdapat doa-doa yang biasanya tidak dibaca setiap hari, seperti doa shalat istikharah, doa hendak melakukan perjalanan dan doa-doa lainnya yang sifatnya dibaca insidental. Seperti ketika melihat kilat dan mendengar gemuruh petir, mendapati hujan, menyambut kelahiran bayi dan sebagainya. ${ }^{32}$

Pada dasarnya, melalui pembacaan wirid al-Ma'tsūrāt ini al-Bana menghendaki umat Islam agar senantiasa berzikir sebagai media taqarrub kepada Allah Swt. Dalam mendorong umat Islam untuk mengikuti rutinitas zikir tersebut, Ia pun jelaskan dengan berbagai argumen yang dilandasi hadis-hadis yang mengungkapkan keutamaan alQur'an. Sehingga, yang terpenting adalah bagaimana seorang muslim mampu menjadikan al-Ma'tsūrāt sebagai media lain untuk membiasakan diri membaca alQur'an. Dalam hal ini, menurut Ahmad Rafiq bahwa al-Qur'an berperan dalam fungsinya sebagai petunjuk sejati bagi pembaca dalam rangka mendekatkan diri kepada Allah Swt. serta mengharapkan surga-Nya. ${ }^{33}$

Berdasarkan pemaparan di atas, maka dapat dilihat keutamaan al-Qur'an dalam fungsinya sebagai al-dzikr. Karena itu, al-Qur'an yang dijadikan sebagai media berzikir dapat menyembuhkan penyakit rohani yang ada di hati setiap kaum muslimin. Terlebih lagi, al-Bana yang juga pernah menjadi salah satu anggota tarekat al-Hashafiyyah alSyadziliyyah dan mendapat ijazah wirid-wirid yang dibaca setiap pagi dan petang. Sehingga, tidak mengherankan apabila penyusunan kitab al-Ma'tsūrāt ini dilakukan dalam rangka mengajak kaum muslimin agar senantiasa mendekatkan diri kepada Allah Swt. dengan selalu membaca wirid yang ada di dalamnya di samping meraih petunjuk dan keutamaannya.

\footnotetext{
${ }^{32}$ Hasan al-Bana, al-Ma'tsūrāt (t.tp: t.p, t.t), 6-22.

${ }^{33}$ Ahmad Rafiq, "Fadhā'il al-Qur'ān", dalam Abdul Mustaqim, dkk. Melihat Kembali Studi AlQur'an: Gagasan, Isu dan Tren Terkini (Yogyakarta: Ide Press, 2015), 43.
} 


\section{Pandangan Hasan al-Bana Terhadap Dzikir}

Pada dasarnya, dzikir ini merupakan salah satu cara kaum muslim untuk mendekatkan diri kepada Allah Swt. Dzikir harus menjadi kebutuhan prioritas bagi mereka. Biasanya, berupa bacaan-bacaan yang telah disusun para ulama terdahulu yang mengandung ayat-ayat al-Qur'an dan doa-doa pilihan. Tentunya, susunan tersebut telah terukur oleh para penyusunnya. Ada banyak jenis dzikir yang dapat dibiasakan oleh kaum muslim, baik itu secara sendirian atau berjama'ah. Kebanyakan, dzikir yang dibaca kaum muslim itu terikat dengan waktu. Misalnya, wirid setelah shalat fardhu, dzikir pagi dan petang, dan salah satunya yang akan menjadi fokus kajian di sini adalah wirid al-Ma'tsūrāt.

Selain menyusun kitab al-Ma'tsūrāt, Hasan al-Bana juga telah memberikan tunt unan berdzikir di dalam pendahuluan kitabnya. Ia menganjurkan agar kaum muslim berdzikir tanpa terikat waktu. Ini dilakukan sebagai bentuk rasa syukur kepada Allah Swt. di samping sebagai upaya untuk menjaga kebersihan hati dan mensucikannya. Bahkan, hal ini telah dicontohkan oleh Rasulullah Saw. pada masanya. ${ }^{34}$ Karena, setiap manusia tentu memiliki tujuan bagi kehidupannya masing-masing yang tidak mungkin diupayakan sendiri tanpa melibatkan Allah Swt. Sehingga, seorang muslim harus berupaya untuk berdzikir yang dirangkaikan dengan doa memohon perlindungan dan hidayah-Nya.

Menurut al-Bana, dzikir kepada Allah Swt. tidak boleh terikat dengan waktu tertentu. Olehnya, dzikir dianjurkan untuk dilakukan sepanjang waktu dalam berbagai bentuk aktifitas sebagaimana telah dicontohkan oleh Nabi Saw. pada masa hidupnya. Adapun tatacara dan adab berdzikir meliputi beberapa hal sebagai berikut:

1. Khusyū', beradab dan berupaya merenungi makna-maknanya agar dapat mengamalkan nilai-nilai yang terkandung di dalamnya.

2. Menyesuaikan terhadap kondisi jama'ah, jika dzikir dilakukan secara berjama'ah. Sehingga, tidak terjadi saling mendahului atau mengakhirkan bacaannya. Karena, yang diharapkan ialah membaca dzikirnya secara serentak bersama-sama.

3. Menjaga kebersihan dan kesucian pakaian maupun tempat dzikir. Di samping itu, juga memilih tempat-tempat yang baik dan waktu yang sesuai dengan dzikir.

4. Meninggalkan tempat dzikir dalam keadaan khusyū' dan penuh adab, dengan menghindari hal-hal yang bernuansa candaan, gurauan maupun hal-hal yang berakibat menghilangkan faedah dzikir tersebut. ${ }^{35}$

Dengan demikian, dapat dipahami bahwa pandangan Hasan al-Bana terhadap dzikir sangat apresiatif. Ini terbukti di dalam pengantar kitab al-Ma'tsūrātyang disusun sendiri. Dalam kitab tersebut, bisa dilihat al-Bana cukup komprehensif ketika menjelaskan konsep dzikir disertakan landasan ayat-ayat al-Qur'an dan hadis-hadis

\footnotetext{
${ }^{34} \mathrm{Al}-\mathrm{Bana}$, al-Ma'tsūrāt, 3.

${ }^{35}$ Al-Bana, al-Ma'tsūrāt, 3-5.
} 
shahih. Sehingga, dengan merujuk pengantar kitab al-Ma'tsūrāt itu, penulis menilai bahwa al-Bana telah memberikan tuntunan kepada masyarakat dalam mengamalkan wirid tersebut. Tanpa berlebihan, dapat dikatakan mengamalkan wirid al-Ma'tsūrāt akan mendapatkan keutamaan-keutamaan ayat-ayat al-Qur'an yang tersusun di dalamnya.

\section{Tradisi Wirid al-Ma'tsūrāt di SMAIT Abu Bakar}

Pembacaan wirid merupakan salah satu rangkaian kegiatan yang biasanya dilakukan setelah melaksanakan shalat fardhu, baik secara sendirian maupun berjama'ah. Di Indonesia sendiri, masyarakat secara umum mengamalkan tradisi wirid tersebut. Seakan-akan itu telah menjadi sebuah tradisi yang melekat dan bahkan seperti bagian dari shalat itu sendiri. Bacaan wirid tersebut memiliki bentuk susunan berbeda di antara beberapa kelompok komunitas muslim. Akan tetapi, perbedaan susunan wirid tersebut tidak mengurangi esensinya sebagai perantara berdoa kepada Allah Swt. Salah satunya, yang populer dibaca oleh masyarakat adalah wirid al-Ma'tsūrāt. Pembacaan wirid al-Ma'tsūrāt ini menjadi salah satu rutinitas bagi siswa di SMAIT Abu Bakar Boarding School Kulon Progo.

SMAIT Abu Bakar Boarding School terletak di Jl. Nyi Ageng Serang No. 16, Dusun Ngrandu, RT. 02/RW. 01 Triharjo, Kec. Wates, Kab. Kulon Progo. Sekolah ini baru beroperasi sejak tahun 2017 dengan siswa yang datang dari berbagai wilayah di Indonesia. Sekolah ini baru memiliki satu jurusan peminatan, yakni IPA bagi para siswanya. Namun, dalam kesehariannya kegiatan di sekolah ini hampir mirip seperti pesantren-pesantren pada umumnya. Para siswa tidak hanya sekolah di pagi harinya saja, akan tetapi mereka juga mendapatkan materi keagamaan dan pengajian al-Qur'an di luar Kegiatan Belajar Mengajar (KBM) reguler sesuai dengan aturan Dinas Pendidikan. Mereka juga dibekali kemampuan berbahasa Inggris dan Arab sebagai salah satu keunggulan sekolah ini.

Di samping itu, mereka harus menghafal al-Qur'an sebagai standar kelulusannya. Adapun target hafalan yang harus dicapai bagi siswa adalah 10 juz selama tiga tahun. Dalam hal ini, sangat cocok bagi siswa untuk membiasakan wirid alMa'tsurat yang sebagian kandungannya berupa ayat-ayat pilihan dari al-Qur'an. Hemat penulis, ini sesuai dengan semangat yang diusung sekolah untuk menghasilkan standar lulusan yang menguasai hafalan $10 \mathrm{juz}$ al-Qur'an. Setidaknya, membaca wirid alMa'tsūrāt merupakan sebagian cara untuk membiasakan diri berinteraksi bersama alQur'an.

Sebagaimana telah menjadi sebuah rutinitas kegiatan harian siswa di SMAIT Abu Bakar Boarding School, membaca wirid al-Ma'tsūrāt seakan bagian dari kebutuhan. Hal itu empat sehat lima sempurna seperti terdapat pada pola makanan. Sehingga, pengurus Sekolah sejak awal memang telah mencanangkan pembacaan alMa'tsūrāt ini sebagai program harian yang wajib diikuti semua siswa. Karena, semua siswa yang ada di sekolah ini merupakan siswa yang bermukim di asrama sekolah yang 
populer disebut santri. Mereka wajib mengikuti rutinitas kegiatan yang telah dijadwalkan jauh sebelumnya. salah satunya ialah membaca wirid al-Ma'tsūrāt pada setiap pagi dan petang, di waktu setelah shalat Shubuh dan shalat Asar.

Wirid ini tersusun dari beberapa ayat al-Qur'an dan doa-doa. Di dalam kitab alMa'tsūrāt dijelaskan ada dua jenis wirid al-wazh̄̄fah, yakni al-wazhīfah al-kubrā dan al-wazhīfah al-shughrā. Adapun yang dibaca oleh siswa SMAIT Abu Bakar adalah alwazhī fah al-shughrā yang merupakan ringkasan dari al-wazh relatif lebih singkat dan sedikit lebih cepat untuk dibaca. Untuk membacanya, para siswa perlu waktu 15 sampai 25 menit lamanya yang dipimpin oleh salah seorang di antara mereka.

Bagi mereka, wirid al-Ma'tsūrāt ini merupakan salah bacaan dzikir yang populer sesuai dengan hadis-hadis Nabi Saw. Berdasarkan hasil wawancara dengan beberapa siswa, menyatakan bahwa:

"al-Ma'tsūrāt ini merupakan kumpulan bacaan dzikir yang berisi ayatayat al-Qur'an dan doa-doa yang sesuai dengan hadis Nabi Saw. Tradisi membaca wirid al-Ma'tsūrāt merupakan salah satu upaya yang sangat bagus untuk membentuk karakter dan membina kondisi lahir batin diri kita. Hendaknya ketika membaca wirid tersebut dilakukan secara berjamaah seperti yang telah dibiasakan di sekolah ini. Namun, seringkali terjadi ketidaknyamanan kalau pemandu wirid tersebut kurang fasih bacaannya. Sehingga, menimbulkan rasa berbeda terkait kekhusyu'an dalam berdoa. Oleh karena itu, seharusnya sebelum membiasakan wirid ini terlebih dahulu harus menguasai walaupun tidak hafal secara keseluruhan. Pembacaan wirid al-Ma'tsūrāt ini dapat dijadikan sebagai perantara untuk taqarrub kepada Allah Swt. di samping sebagai sarana pengobatan jiwa dan motivasi diri."

Pembacaan wirid al-Ma'tsūrāt ini dilakukan secara rutin tiap hari pada waktu pagi dan sore. Sebab, pembacaan seperti itu dapat menimbulkan dampak positif bagi pembacanya. Bukan saja dapat menenangkan jiwa, melainkan pula bisa menciptakan suasana kedamaian hidup sepanjang hari. Sebagaimana dijelaskan penyusun kitab yang diungkapkan dalam Mukaddimahnya bahwa:

"Maka, aku berpesan dengan wirid al-Wazhifah ini kepada Ikhwan alMuslimin secara khusus dan kepada kaum muslimin secara umum supaya dapat menolong mereka untuk taat kepada Allah Swt. Wirid ini dibaca pada waktu pagi, mulai Shubuh hingga Zuhur dan pada waktu sore, mulai Asar hingga Isya' baik sendirian maupun berjama'ah. Dzikir kepada Allah seperti ini telah dilakukan oleh Rasulullah dalam segala keadaan. Maka, hendaknya dapat menghafal isi kumpulan bacaan dzikir ini sebagai media untuk taqarrub kepada Allah Swt." ${ }^{36}$

Secara jelas, kutipan di atas menunjukkan bahwa kitab al-Ma'tsūrāt disusun bukan untuk satu golongan saja, melainkan untuk kaum muslimin secara umum.

\footnotetext{
${ }^{36} \mathrm{Al}-\mathrm{Bana}$, al-Ma’tsūrāt, 5.
} 
Adapun waktu membacanya dianjurkan pada waktu pagi dan sore. Tidak jarang oleh masyarakat wirid ini disebut sebagai wirid pagi dan petang. Karena, di dalam satu doanya terdapat doa yang menunjukkan keterangan yang disesuaikan dengan konteks waktunya. Salah satu penggalan doa tersebut, terdapat kata ashbaha (berarti waktu pagi) dan kata amsā (berarti waktu sore). Kedua kata ini bergantian dibaca menurut waktu pembacaan dilakukan.

Adapun waktu pembacaan wirid al-Ma'tsūrāt yang dilakukan di SMAIT Abu Bakar adalah pagi setelah shalat Subuh dan sore setelah shalat Asar. Semua siswa wajib mengikuti tradisi pembacaan wirid ini. Dengan membaca wirid tersebut, diharapkan mereka dapat mengoptimalkan fungsi al-Qur'an sebagai media dzikir dan al-Syifa'. Pembaca wirid tersebut akan memperoleh kedamaian hati yang dapat berpengaruh terhadap kesehatan psikologisnya. Kesehatan tersebut dapat berdampak terhadap motivasi dan prestasi belajar siswa selama di sekolah.

Di dalam al-Ma'tsūrāt sendiri, terdapat ayat-ayat tertentu yang memiliki keutamaan sesuai dengan landasan hadis masing-masing. Seseorang yang membacanya diyakini akan mendapatkan keutamaan tersebut. Karena, seseorang yang membaca ayat-ayat tersebut berarti berupaya menghidupkan al-Qur'an dalam kehidupan seharihari. Sehingga, ketika seseorang membaca al-Ma'tsūrāt secara rutin (pagi dan sore) secara tidak langsung akan mendapatkan beberapa keutamaan sebagai berikut:

1. Perlindungan tempat tinggal dari gangguan setan.

Hal ini sesuai dengan hadis Nabi Saw. bahwa:

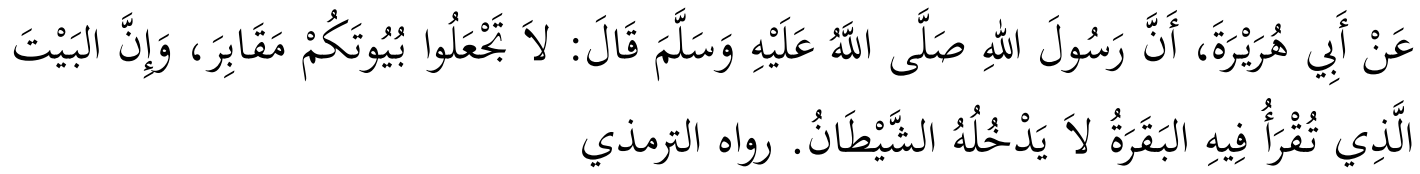

Artinya: "Dari Abu Hurairah RA., sesungguhnya rasulullah Saw. bersabda: "Jangan jadikan rumah-rumahmu seperti kuburan. Sesungguhnya rumah yang dibacakan surah al-baqarah, setan tidak akan masuk ke dalamnya." ${ }^{37}$

Dalam wirid al-Ma'tsūrāt terdapat 10 ayat surah al-Baqarah, yakni empat pertama surah al-Baqarah, ayat kursi dan dua ayat setelahnya, serta ditutup dengan tiga ayat terakhir dari surah al-Baqarah. Maka, dengan mengacu kepada hadis di atas, sangat dianjurkan untuk rutin membaca al-Ma'tsūrāt yang memuat 10 ayat surah alBaqarah yang sudah jelas keutamaannya. ${ }^{38}$

2. Mendapatkan pahala membaca $1 / 3$ al-Qur'an.

Hal ini sesuai dengan hadis Nabi Saw.:

${ }^{37} \mathrm{HR}$. Tirmidzi.

${ }^{38}$ Abu İsā Muhamad bin Isā bin Sūrah bin Mūsā bin al-Dlaḥhāk al-Tirmidzi, Sunan al-Tirmidzi, Cet. II (Riyādl: Dār al-Ḥaddlārah, 2015), 557. Lihat juga di Muhammad Salim Muhsin, Fadllu Qirā 'ah Ba'dlu Āyāt wa Suwar al-Qur'ān al-Kan̄im (Kairo: Dār Mahīs, 2002), 13. 


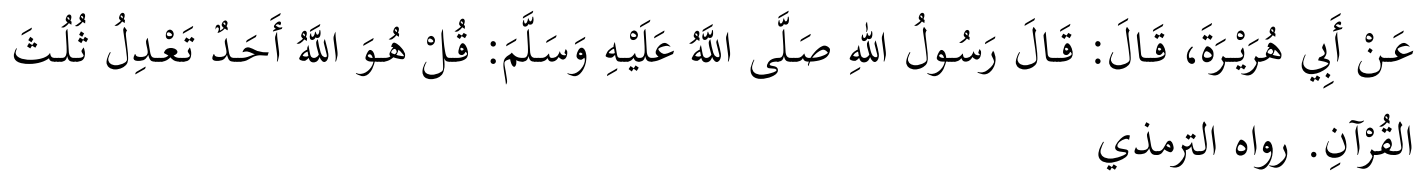

Artinya: "Dari Abu Hurairah RA. berkata: Rasulullah Saw. Bersabda:"Qul huw Allāhu Ahad itu sebanding dengan 1/3 al-Qur'an". ${ }^{39}$

Berdasarkan hadis tersebut, mengandung informasi bahwasanya surah al-Ikhlas sangat besar pahalanya. Satu kali membaca al-Ikhlas sebanding dengan 1/3 al-Qur'an. Hal ini dapat diartikan jika tiga kali membaca surah al-Ikhlas sama dengan membaca seluruh al-Qur' an. ${ }^{40}$

3. Sebagai bentuk rasa syukur kepada Allah Swt.

Hal ini sesuai dengan hadis Nabi Saw.:

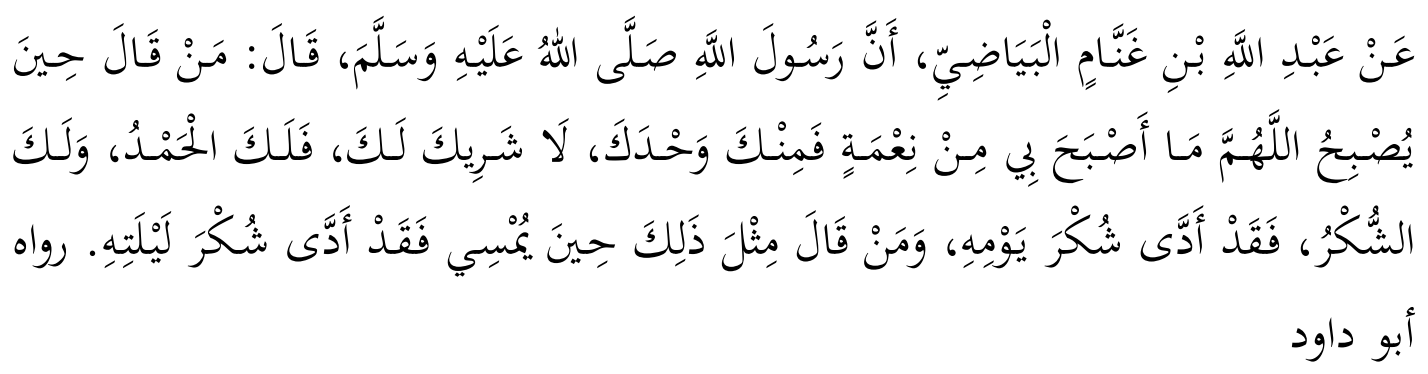

Artinya: "Dari Abdullah bin Ghannām al-Bayādhī, bahwa rasulullah Saw. bersabda: "Barangsiapa yang membaca saat paginya doa, "Ya Allah, tidaklah menyertaiku di waktu pagi dari sebuah nikmat yang tentu dari-Mu, yang tiada sekutu bagi-Mu. Maka bagi-Mu segala puji, bagi-Mu rasa syukur," maka dia telah bersyukur sepanjang hari. Dan barangsiapa yang mengucapkan doa yang sama di sore harinya, maka dia telah bersyukur sepanjang malamnya." ${ }^{41}$

Hadis di atas memberikan penjelasan bahwa ketika doa dalam hadis itu dibaca di pagi harinya, akan menjadi pertanda rasa syukur sehari penuh. Begitu pun ketika doa tersebut dibaca di sore harinya, maka akan dinilai sama sebagai orang yang bersyukur semalam suntuk hingga pagi. ${ }^{42}$

4. Terjaga dari gangguan sepanjang hari.

Hal ini sebagaimana dalam hadis:

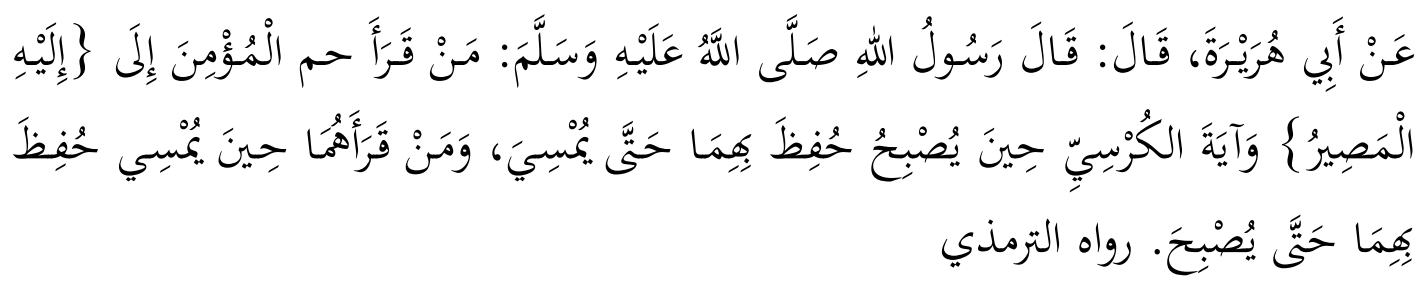

\footnotetext{
${ }^{39} \mathrm{HR}$. Tirmidzi

${ }^{40}$ Al-Tirmidzi, Sunan al-Tirmidzi, 561.

${ }^{41}$ HR. Abu Dawud.

${ }^{42}$ Sulaimān bin al-Asy'ats bin Isḥāq bin Basyīr al-Azdī al-Sijistān̄̄, Sunan Ab̄̄ Dāwud (Riyādl: Dār al-Hadlārah li al-Nasyr wa al-Tauz̄̄’, 2015), 628.
} 
Artinya: "Dari Abu Hurairah berkata: Rasulullah Saw. bersabda: "Barangsiapa yang membaca awal surah al-Mu'min hingga akhir ayat ilaihi al-mashīr dan ayat kursi ketika pagi, maka akan dijaga dengan keduanya hingga sore hari. Begitu pun, barangsiapa membaca keduanya ketika sore, maka akan dijaga dengan keduanya hingga pagi hari". ${ }^{43}$

Dalam konteks ini, hadis di atas relevan sebagai tuntunan agar seseorang membaca ayat kursi. Seperti disebutkan dalam hadis tersebut, pembaca ayat kursi akan mendapat perlindungan sepanjang hari. ${ }^{44}$

Keempat hal di atas merupakan sebagian keutamaan yang dapat diperoleh dari rutinitas membaca wirid al-Ma'tsūrāt. Berdasarkan pemaparan di atas, dapat dikatakan bahwa beberapa ayat al-Qur'an di dalam al-Ma'tsūrāt merupakan ayat-ayat pilihan yang mengandung keutamaan-keutamaan. Hemat penulis, ayat-ayat tersebut merupakan serangkaian bacaan yang memiliki keutamaan ketika dibaca. Boleh dikatakan bahwa wirid al-Ma'tsūrāt ini memang disusun seperti obat bagi umat muslim yang bersedia untuk memanfaatkannya.

Beberapa siswa pun telah merasakan manfaat dari rutinitas pembacaan wirid tersebut selama ini. Sebagian di antara mereka menilai bahwa wirid tersebut penting untuk melengkapi serangkaian aktifitas sehari-hari. Bahkan, jika melewatkan tidak sempat membacanya akan terasa ada sesuatu yang kurang. Demikian seperti dijelaskan Umar:

"Dulu ketika masih duduk di bangku SMP, rutinitas pembacaan wirid alMa'tsūrāt tidak seperti di sini. Ketika itu, di sekolah hanya diwajibkan untuk membaca sekali saja setiap pagi. Namun, wirid ini saya biasakan tidak hanya di sekolah saja. Terkadang saat di rumah, ketika sore juga menyempatkan waktu untuk membacanya. Jika tidak membacanya terasa ada yang kurang. Oleh karena itu, rutinitas pembacaan wirid al-Ma'tsūrāt ini sangat bermanfaat bagi pembacanya. Terlebih lagi, jika mau memahami makna dan artinya terlebih dahulu. Dampaknya akan lebih terasa. Di antaranya, dapat menjadi obat bagi jiwa yang sakit dan juga dapat dijadikan sebagai media pembinaan karakter bagi para siswa."

Dari pemaparan di atas, penulis menilai bahwa tradisi membaca al-Ma'tsūrāt harus dimaknai bukan sekadar ritual membaca semata. Keberlangsungan program baca al-Ma'tsūrāt tersebut boleh dimaknai sebagai resepsi masyarakat terhadap al-Qur'an. Terbukti bahwa sebagian pembacanya telah merasakan manfaat untuk menjaga stabilitas kerohanian mereka. Selain itu, juga berperan menjadikan para siswa lebih tenang dalam menjalankan setiap aktifitas harian yang ada di sekolah. Sehingga, dari sinilah nampak fungsi al-Qur'an sebagai kitab petunjuk sejati yang hidup di tengahtengah pembacanya.

Dengan demikian, dipahami bahwa tradisi membaca wirid al-Ma’tsūrāt di sebuah institusi atau lembaga sekolah bukan sekadar ikut-ikutan tanpa landasan. Akan

\footnotetext{
${ }^{43}$ HR. Tirmidzi

${ }^{44}$ Al-Tirmidzi, Sunan al-Tirmidzi, 557.
} 
tetapi, pembacaan wirid semacam itu dilakukan sebagai tradisi untuk menjaga kesehatan spiritual. Di sisi lain, wirid tersebut juga dijadikan perantara untuk mencapai tingkat kesadaran terhadap kebesaran Allah Swt. dan kekuasaan-Nya. Sehingga, para pembaca wirid al-Ma'tsūrāt akan memperoleh kesembuhan kejiwaannya. Lebih dari itu mereka juga menjadikannya sebagai media untuk taqarrub kepada Allah Swt. untuk meraih derajat ketakwaan di hadapan-Nya.

\section{Penutup}

Konsep wirid qur'ani yang terangkum dalam al-Ma'tsūrāt oleh Hasan al-Bana mengajak segenap umat muslim untuk membiasakannya minimal setiap pagi dan sore. Bacaan wirid al-Ma'tsūrāt yang menjadi rutinitas harian bagi siswa di SMAIT Abu Bakar Kulon Progo ini tergolong al-wazhīfah al-shughrā, yakni al-Ma'tsūrat versi ringkasnya. Tujuan dari membaca wirid al-Ma'tsūrāt ialah untuk mengungkapkan rasa syukur kepada Swt. sepanjang waktu dan melatih agar terbiasa berinteraksi dengan alQur'an. Di samping sebagai wirid harian, membaca al-Ma'tsūrāt juga diharapkan agar memperoleh keutamaan-keutamaannya.

Dengan demikian, dipahami bahwa wirid al-Ma'tsūrāt di SMAIT Abu Bakar Boarding School Kulon Progo merupakan bagian dari Living Quran. Para siswa yang menjalankan rutinitas tersebut setiap pagi dan sore menunjukkan adanya upaya menghidupkan al-Qur'an di tengah-tengah mereka. Selain itu, membaca sebagian ayatayat tertentu yang tersusun di dalamnya menjadi satu bentuk resepsi fungsional dari keberadaan al-Qur'an dalam kehidupan sehari-hari. Sehingga, al-Qur'an bukan lagi menjadi teks yang mati ketika ada upaya untuk menghidupkannya di tengah-tengah masyarakat dan menjadikannya sebuah tradisi.

\section{DAFTAR PUSTAKA}

Al-Ashfihān̄̄, Rāghib. al-Mufradāt fi Ghan̄̄b al-Qur'ān, Beirut: Dār al-Ma'rifah, t.th. Arti Kata Wirid, pada situs https://kbbi.web.id/wirid diakses pada 06 Oktober 2019. Al-Bana, Hasan. al-Ma'tsūrät, t.tp: t.p, t.t.

Faizin, Hamam. "Mencium dan Nyunggi Al-Qur'an”, Jurnal Suh uf 4, no. 1 (2011).

Jannah, Nur. "Pengaruh Zikir al-Ma'tsurat dan Terjemahannya Terhadap Penurunan Kecemasan Siswa Menghadapi Ujian Nasional”, Jurnal Studia Insania 5, no. 2 (2017).

Jannah, Raudhatul. "Pemikiran Pendidikan Islam Hasan Al-Bana", Jurnal Analytica Islamica 6, no. 1 (2017).

Muhsin, Muhammad Salim. Fadllu Qirā 'ah Ba'dlu Āyāt wa Suwar al-Qur'ān al-Kañm, Kairo: Dār Maḥ̄̄s, 2002. 
Muhtador, Moh. "Pemaknaan Ayat Al-Qur'an Dalam Mujahadah; Studi Living Qur'an di PP. Al-Munawwir Krapyak Komplek Al-Kandiyas", Jurnal Penelitian 8, no. 1 (2014): 108-109.

Munawwir, Ahmad Warson. Kamus Al-Munawwir, cet. XIV, Surabaya: Penerbit Pustaka Progressif, 1997.

Najati, Muhammad Utsman. Psikologi Qur'ani; Psikologi dalam Perspektif Al-Qur'an, terj. Amirussodiq, Solo: Aulia Press, 2007.

al-Nawawi, Yahya bin Syaraf. al-Tibyān fi Adāb Hamalat al-Qur'ān, Beirut: Maktabah al-Muayyad, 1991.

Otoman. "Pemikiran Politik Hasan Al-Bana dan Pembentukan Radikalisme Islam", Jurnal Tamaddun 15, no. 1 (2015).

Padmopuspito, Asia. "Teori Resepsi dan Penerapannya", Jurnal Diksi 1, no. 02, (1993).

Rafiq, Ahmad. "Fadhā'il al-Qur'ān", dalam Abdul Mustaqim, dkk. Melihat Kembali Studi Al-Qur'an: Gagasan, Isu dan Tren Terkini, Yogyakarta: Ide Press, 2015. . "Sejarah Al-Qur'an: Dari Pewahyuan ke Resepsi (Sebuah Pencarian Awal Metodologis)", dalam Sahiron Syamsuddin, Islam, Tradisi dan Peradaban, Yogyakarta: Bina Mulia Press, 2012.

Rahman, Miftahur. "Resepsi terhadap Ayat al-Kursi dalam Literatur Keislaman", Maghza; Jurnal Ilmu Al-Qur'an dan Tafsir 3, no. 2 (2018):

Saeed, Abdullah. The Qur'an An Introduction, New York: Routledge, 2008.

Shalih, Subhi. Mabāhits fi Uhùm al-Qur'ān, Beirut: Dar al-'Ilmi li al-Malayin, 1977

Shihab, M. Quraish. Tafsir Al-Mishbāh, Pesan, Kesan dan Keserasian al-Qur'an, cet. I, Jakarta: Lentera Hati, 2002.

al-Sijistānī, Sulaimān bin al-Asy'ats bin Isḥāq bin Basyīr al-Azdī. Sunan $A b \bar{\imath} D \bar{a} w u d$, Riyādl: Dār al-Ḥadlārah li al-Nasyr wa al-Tauzī', 2015.

Syamsuddin, Sahiron dkk. Metodologi Living Qur'an dan Hadis, Yogyakarta: Teras, 2007.

al-Tirmidzi, Abu Īsā Muhamad bin Isā bin Sūrah bin Mūsā bin al-Dlaḥhāk. Sunan alTirmidzi, cet. II, Riyādl: Dār al-Ḥaddlārah, 2015.

Wawancara dengan Kepala Sekolah dan Siswa SMAIT Abu Bakar Boarding School Kulon Progo, pada Jum'at 26 April 2019.

al-Zarqān̄i, Muhammad Abdul Azhim. Manāhil al-'Irfān fi Uh̄̄m al-Qur'ān, Jilid II, Mesir: Īsā al-Bāb al-Halabī, t.th.

al-Zuhaily, Wahbah. al-Tafsìr al-Munìr fí al-'Aqūdah wa al-Syan̄'ah wa al-Manhaj, cet. Ke-10, Jilid XIV, Beirut: Dār al-Fikr, 2009. 